\title{
Updating of Makiling Biodiversity Information System (MakiBIS) and Analysis of Biodiversity Data
}

\author{
DAMASA B. MAGCALE-MACANDOG ${ }^{1, \bullet}$, FERMIN ROBERTO G. LAPITAN ${ }^{2}$, JEOFFREY M. LARUYA ${ }^{3}$, \\ JANDREL IAN F. VALERIO ${ }^{2}$, JANZEN CHRISTIAN D. AGUILA ${ }^{2}$, CLOUIE ANN L. MESINA ${ }^{2}$, \\ TWINKLE MARIE F. SANTOS ${ }^{2}$, ANDREA NICOLE T. CUEVAS ${ }^{2}$, KIMBERLY D. BAYLON ${ }^{2}$, \\ IANA MARIENE SILAPAN ${ }^{1}$, RICAJAY DIMALIBOT ${ }^{1}$, JENNIFER D. EDRIAL ${ }^{1}$, NETHANEL JIREH A. LARIDA ${ }^{1}$, \\ FATIMA A. NATUEL ${ }^{4}$, MA. GRECHELLE LYN D. PEREZ ${ }^{4}$, SARENA GRACE L. QUINONES ${ }^{1}$ \\ ${ }^{1}$ Institute of Biological Sciences, University of the Philippines Los Baños. College, 4031 Laguna, Philippines. \\ Tel.: +63-49-5016503, `email: dmmacandog@up.edu.ph; dmmacandog@gmail.com \\ ${ }^{2}$ Institute of Computer Science, University of the Philippines Los Baños. College, 4031 Laguna, Philippines \\ ${ }^{3}$ College of Forestry and Natural Resources, University of the Philippines Los Baños. College, 4031 Laguna, Philippines \\ ${ }^{4}$ School of Environmental Science and Management, University of the Philippines Los Baños. College, 4031 Laguna, Philippines
}

Manuscript received: 11 October 2020. Revision accepted: 20 December 2020.

\begin{abstract}
Magcale-Macandog DB, Lapitan FRG, Laruya JM, Valerio JIF, Aguila JCD, Mesina CAL, Santos TMF, Cuevas ANT, Baylon KD, Silapan IM, Dimalobot R, Edrial JD, Larida NJA, Natuel FA, Perez MAGLD, Quinones SGL. 2021. Updating of Makiling Biodiversity Information System (MakiBIS) and Analysis of Biodiversity Data. Biodiversitas 22: 211-226. Mt. Makiling is a Philippine biodiversity hotspot listed as one of the 170 conservation priority areas established by the Philippine government. With the vast amount of ecological and biological information about the flora and fauna of Mt. Makiling, the Makiling Biodiversity Information System (MakiBIS) was developed to serve as a repository for these data. MakiBIS may serve as a prototype in the development of a national BIS that will be useful in addressing the need to set a national baseline, measurable targets, and indicators to facilitate the assessment of biodiversity status and as a basis for decision-making. The MakiBIS project started in 2011 and was last updated in 2014. In 2019, a new version of the information system was updated to take advantage of current web technologies in software development. The new MakiBIS' (MakiBIS 2.0) frontend was written using ReactJS, while its backend functions were coded using NodeJS, and the database tables were compressed and optimized for faster queries. MakiBIS 2.0 was published online and can be accessed at www.makibis.com. The MakiBIS 2.0 database was populated with biodiversity information from published botanical and faunal survey studies conducted in Mt. Makiling. Biodiversity information includes taxonomic classification, botanical description, habitat, mode of reproduction, economic use, endemism, and conservation status. The MakiBIS database was analyzed for patterns, trends, distribution, and potential threats that will be useful towards the conservation and management of these biodiversity resources.
\end{abstract}

Keywords: Biodiversity information system, conservation status, endemic, MakiBIS, Mt. Makiling, threats, tropical rainforest

\section{INTRODUCTION}

The Philippines is considered one of the 18 megabiodiversity countries, yet at the same as a conservation hotspot (Oliver and Heaney 1997; Panela 2014). The country contains $75 \%$ of the Earth's flora and fauna diversity and ranks fifth in the world in number of plant species. Its biodiversity profile contains $5 \%$ of the world's flora species (Convention on Biological Diversity, n.d.) and of its 9,250 vascular plant species, more than 3,000 species are endemic. Endemism is quite high in the country with 25 genera of plants and $49 \%$ of terrestrial wildlife being endemic and it ranks fourth in the world in the number of endemic bird species (Convention on Biological Diversity, n.d.). The equatorial location of its islands made a range of tropical environments characterized primarily by wide-ranging rainforests (Alcala and Brown 1998; Heaney 1986).

In terms of faunal diversity, the country has the highest rate of discovery of species with 16 new species found in the last 10 years (Conservation international 2008). The
Philippines Biodiversity Management Bureau (2020) provided a list of threatened fauna of the country. Among the faunal groups, of the 530 bird species recorded in the country, around 185 are endemic and more than 60 are in the threatened category. For mammals, over 100 of its 165 species are endemic with 33 species being threatened. The herpetological fauna of the Philippines also holds a number of species unique to the country but are also subjected to the perils of threatened status. There are nearly 90 species of amphibians in this hotspot with more being added to the list as the rate of discovery continues to bring more new species that are mostly already categorized as threatened upon discovery. Sixty-one percent of the Philippines' 235 reptile species are endemic, among which 6 are critically endangered, 5 are endangered, and 3 are vulnerable. The inland waters of the Philippines provide a habitat for 280 types of fishes and 65 species of those are only found in that particular locality but currently facing the greatest risk of extinction.

Mount Makiling is an inactive volcano located in the southern-central of Luzon island, Philippines, and is 
administratively being shared by two provinces, Laguna and Batangas provinces. Mt. Makiling is a low mountain with a peak of only 1,130 meters above sea level (m asl), but still shelters diverse and distinctive forest ecosystems such as lowland rainforest and mossy forest. It was recognized as one of the first national parks in the country in 1933 through Proclamation No. 552. However, it was reclassified as Mount Makiling Forest Reserve (MFR) in 1990 under Republic Act 6967. The 4,224-hectare forest area was transferred under the management of the University of the Philippines (UP) in Los Baños, primarily as a training laboratory for the advancement of scientific and technical knowledge, particularly in the preservation, conservation, and development of the forest, flora and fauna, and natural resources of Mt. Makiling. Also, the government established it as one of the most significant biodiversity conservation areas in the country (Mallari andTabaranza 2001).

Mt. Makiling has a Type I climate based on modified Coronas classification with distinct dry and wet seasons. The dry season is from January to April and the wet season is from May to December (Caldecott 1993). The annual mean temperature of Mt. Makiling ranges from 25.9 to $29.3^{\circ} \mathrm{C}$, with the hottest temperature is recorded from April to July while the coldest is from December to February. The climate in the forest is mainly caused by east and west monsoon and the intertropical convergence zone. In terms of average annual rainfall, the nearest weather station in the forest recorded a range of 1,645 to $2,299 \mathrm{~mm}$ from 2005 to 2010. Generally, MFR has a rocky and steep topography (Fabunan et al. 2008). The soil in the north eastern part is loam-clay from the volcanic materials and ash. On the other hand, the soil in the southwestern part facing Sto. Tomas, Batangas is white-clay that is why the nearest town in the area is named Putinglupa (meaning white soil). The soil $\mathrm{pH}$ is from 4.3 to 6.5 (Pancho 1983).

Considering its long scientific history, Mt. Makiling is recognized as one of the country's eminent biological areas (Pancho 1973, 1983; Fernando et al. 2004). It is a Philippine biodiversity hotspot listed as one of the 170 conservation priority areas by the Philippine government. Further, it is one of the country's 32 key ecotourism sites (DOT-DENR, 2002) and 18 plant diversity centers (DENRCI-UP, 2002). It is also an exceptionally high biodiversity conservation priority zone in the country (Ong et al. 2002).

Various land-use types in Mt. Makiling include forest (482 masl); roadside (455 masl); agroforest (368 masl); buffer zone (365 masl); agricultural farms (355 masl); and mahogany plantation (341 masl) (Alcala et al. 2019). Numerous forest plantations and hardwood species can be found in the forest area under 750 masl. These forest areas have rich vegetation, but only recognized as secondary forest because there are households and human activities in some of its parts. On the other hand, the mossy forests are found in higher elevations above 750 masl. Compared to higher elevation areas, there are more disturbances in lower elevation areas, thus, having low species richness. Indeed, as the elevation increases, the species richness, abundance, and diversity increase as well.
Floral biodiversity surveys conducted in Mt. Makiling reported 148 tree species with 87 indigenous or native species and 44 endemic species (Malabrigo Jr. et al. 2016; Castillo et al. 2018; Abraham et al. 2010); 101 understorey plant species (Macandog et al. 2012); 45 pteridophyte species (Alcala et al. 2019; Macandog et al. 2012), 77 moss species and nine algae species (Alcala et al. 2019; Macandog et al. 2012). The endemic tree species make up $32 \%$ of the country's endemism profile. The crater area of the mountain is composed mainly of undisturbed forests wherein 416 ferns and flowering plant species were identified by Abraham et al. (2010), of which $28 \%$ of the plants are considered endemic.

Abraham et al. (2010) identified 84 birds, 21 amphibians and reptiles, and 12 mammals in Mt. Makiling, of which half of the terrestrial vertebrates were endemic, with one bird species threatened and one mammal rare. Of the 21 amphibians and reptiles (Alcala et al. 1997; Taylor 1992; Abraham et al. 2010), 2 species are exotic and eight are endemic to the country. The mountain's secondary lowland evergreen forest shelters endemic reptile and frog species such as Platymantiscorrugatus and Platymantis dorsalis (Alcala et al. 1997). The 84 bird species (Abraham et al. 2010) include restricted-range bird species such as Philippine Hawk Eagle, Philippine Cockatoo, Luzon Bleeding Heart Pigeon, Philippine Dwarf Kingfisher, Philippine Eagle-Owl, and Green-faced Parrotfinch (Gonzalez 1997). Some of the identified endemic small non-volant mammals in Mt. Makiling include the Philippine forest rat, Luzon shrew, small Luzon forest mouse, and a new species of Apomys (de Guia et al. 2011). A survey by Alvarez et al. (2015) in MFR identified new bats fly species such as Cyclopodia garrula Maa, $C$. horsfieldide Mejeire, Eucampsipoda philippinensis Ferris, Penicillidia acuminate Theodor, and Phthiridiumbra chyacantha Theodor. Also, they identified C. garrula as a new record in Luzon.

Along the elevational slopes on the northeastern side of Mt. Makiling, 27 filamentous fungi genera and three actinomycete families were identified (Macandog et al. 2012). A study by Nacua et al. (2018) on the macrofungal diversity in the Makiling Botanic Gardens (MBG) vicinity at the Makiling Forest Reserve (MFR) revealed that out of the 21 macrofungal taxa collected, 20 are from Basidiomycota and only one from Ascomycota. The Polyporaceae was identified as the most prevailing macrofungi family (24\%). There were six (6) medicinal species and no existing poisonous species identified. One the other hand, Paquit (2017) observed greater fungal diversity in undisturbed forests with Cantharellus spp. having the highest number of individuals.

About 118 arthropod species were identified from 50 known families with 84 species, three unidentified families with 29 species, and four unidentified genera with five species. Most of these arthropods signify less disturbed forests (Abraham et al. 2010). Likewise, de Chavez and de Lara (2011) reported that the endemic macro land snails were more diverse and abundant in undisturbed forests. They identified 14 species and families of Achatinidae, Bradybaenidae, Camaenidae, Cyclophoridae, and 
Helicarionidae. Ryssotao taheitana $(41.47 \%)$ was the most abundant species found. Further, Macandog et al. (2012) identified 15 land snail species along the eastern slopes of Mt. Makiling.

A total of 1,358 aquatic macroinvertebrates from 22 families were collected in the watershed streams of Molawin, Cambantoc, and Sipit of Mount Makiling. The Hexapods (16 families) were highly abundant (74\%) in the streams, followed by gastropods $(14 \%)$. The MFR is a significant biological sanctuary as it shelters complex macroinvertebrate diversity in its watersheds (Parcon et al. 2020).

With this vast amount of ecological and biological information in Mt. Makiling, the use of information and communication technologies will greatly help in its management (Roy et al. 2002). This detailed information on species diversity is important for establishing relationships among various groups of organisms living in the forest and determining the effects of their relationship to their function and structure in the ecosystem (Staley and Reysenbach 2001). The management of biodiversity information is a crucial part of the works in biodiversity as the decision-making on sustainable development and biodiversity conservation must be based on accurate and comprehensive information and data (Dai 2012). Using GIS, geodatabase of MFR was developed to be used in planning, designing, and implementing biodiversity conservation and forest renewal programs (Bantayan et al. 2008).

In the case of Mt. Makiling, the Makiling Biodiversity Information System (MakiBIS) was developed to serve as a repository for these data. Maintaining a BIS is essential as the University of the Philippines at Los Baños (UPLB) aspires to lead in biodiversity research. An initial version of the Makiling Biodiversity information system (MakiBIS 1.0) was developed in 2011 (Lapitan et al. 2013). MakiBIS manages taxonomic information of Mt. Makiling species that follow the Darwin core standards and provide the functionality to share information through an XML dataset exporter. MakiBIS may serve as a prototype in the development of a national BIS that will be useful in addressing the need to set a national baseline, measurable targets, and indicators to facilitate the assessment of biodiversity status and as a basis for decision-making.

This paper will describe the updating and improvement of the structure and framework of MakiBIS using current web technologies that would manage the taxonomic information of the species in Mt. Makiling. The continuation of the MakiBIS development will be useful in sharing biodiversity data with other international information systems like the Global Biodiversity Information Facility (GBIF). On top of taxonomic classification information, the Mt. Makiling biodiversity data will be analyzed for patterns and distribution, identification of potential threats, and proposal of strategies towards conservation and management of these biodiversity resources.

\section{MATERIALS AND METHODS}

\section{MakiBIS version 2 software development \\ Software tools}

MakiBIS 2.0 was developed using React for its frontend and user interfaces. On the other hand, the backend processes and the web server were coded using NodeJS with packages such as express-mysql-session, mysql, axios, cors, react-redux, and semantic-ui. As for the database management system, MakiBIS 2.0 now uses MariaDB, which is an open source fork of MySQL.

\section{Coding, testing, and online deployment}

Three pairs of software developers were assigned to work on the frontend, backend, and database modules of MakiBIS 2.0. The frontend developers designed and implemented the graphical user interface of the system using React, which is a JavaScript library for creating user interfaces. The database developers were responsible for redesigning the database schema, updating the table names and attribute data types, and writing the queries needed to retrieve information from the database. The backend developers converted most of the PhP-based functions from the old system to NodeJS compatible functions. Additional functions were also written by the backend developers and they were responsible for connecting the frontend interfaces to the server. After integrating the modules, MakiBIS 2.0 was tested at the developer level and the errors found were resolved. MakiBIS was then deployed in an Ubuntu droplet from DigitalOcean (www.digitalocean.com) and can be accessed in www.makibis.com.

\section{MakiBIS biodiversity data population}

The MakiBIS database was encoded using an Excel spreadsheet wherein each row represents a species. The information on taxonomy, species author, biological description, habitat, mode of reproduction, endemism, conservation status, photo, and references comprise the columns of the table. The floral and faunal lists as well as the botanical and habitat descriptions were derived from published books on biodiversity surveys conducted in Mt. Makiling. Additional information on conservation status, endemism, and mode of reproduction were collected from various journal articles and biodiversity web databases. The spreadsheet was then converted to a CSV file then imported to MakiBIS 2.0.

The biodiversity data contained in the MakiBIS database were analyzed for floral and faunal composition, endemism, conservation status, threats, and trends related to various factors including anthropogenic activities.

\section{RESULTS AND DISCUSSION}

\section{MakiBIS 2.0 updates from version 1}

The information system was updated and improved with current web technology, computer software, database technology, and hardware technology. It has significantly enhanced the data management standardization, level of 
information use, and speed of information dissemination and led to a lower cost, higher efficiency, and better impact in management. The utilization of information systems for management, storage, use, and exchange of biodiversity information is the expected result of adjusting to the information age and usual option to strengthen the use and protection of biodiversity (Dai 2012).

With the continuous growth in database technology and the Internet, the structure of BIS also changed from traditional mode to advanced structure. Therefore, the users can now access the world's rich, developing, and changing biodiversity information service just through the integrated browser interface. International biodiversity database, regional, and national data nodes are being progressively established and the BIS is progressing to an open and shared network (Dai 2012).

The background database utilized in the biodiversity information system is also evolving from small desktop database to large business database, supporting Internet access such as Oracle and SQL Server. Also, the structure of biodiversity database is now more complex, from structured data like text and relational type data to nonstructured data containing multimedia and pictures (Zhao et al. 2000; $\mathrm{Xu}$ 1998).

In the case of MakiBIS, it has been created as repository of biodiversity data. The information included in the MakiBIS is taxonomy, botanical description, habitat, mode of reproduction, endemicity, economic use, conservation status, and photo. The MakiBIS 1.0 was developed in 2011. It follows the Darwin core standards and provides the functionality to share information through an XML dataset exporter.
Further updating and improvement of the MakiBIS structure and framework using current web technologies were done. The updating of MakiBIS will be helpful in sharing and exchanging biodiversity data with other international information systems such as GBIF. Aside from taxonomic classification information, the biodiversity data will be analyzed for patterns and distribution, determination of potential threats, and planning strategies towards biodiversity conservation and management.

\section{Backend updates}

The backend functions of MakiBIS 1.0 were developed using PHP and used the Apache webserver. For MakiBIS 2.0, NodeJS was used to rewrite these functions as well as create the webserver. Google log-in was also added as a new feature. It allows UP constituents to $\log$ in using their UP mail accounts and access the site as guests. In the future, these users will have slightly higher privileges in using MakiBIS 2.0.

\section{Frontend updates}

The frontend of MakiBIS was updated from being written using PhP/JQuery to ReactJS. The updated user interface now loads much faster and has a cleaner and more current look. Figures 1 to 3 show the screenshots of the updated user interface of MakiBIS.

The Landing Page is the first page that a user sees upon visiting MakiBIS 2.0 (Figure 1). The current number of species and subspecies can be found at the bottom of the page. Users can also sign in or register on the landing page. The mid-upper section of the page shows some links to other pages of MakiBIS such as Species, Taxonomy Tree, and References.
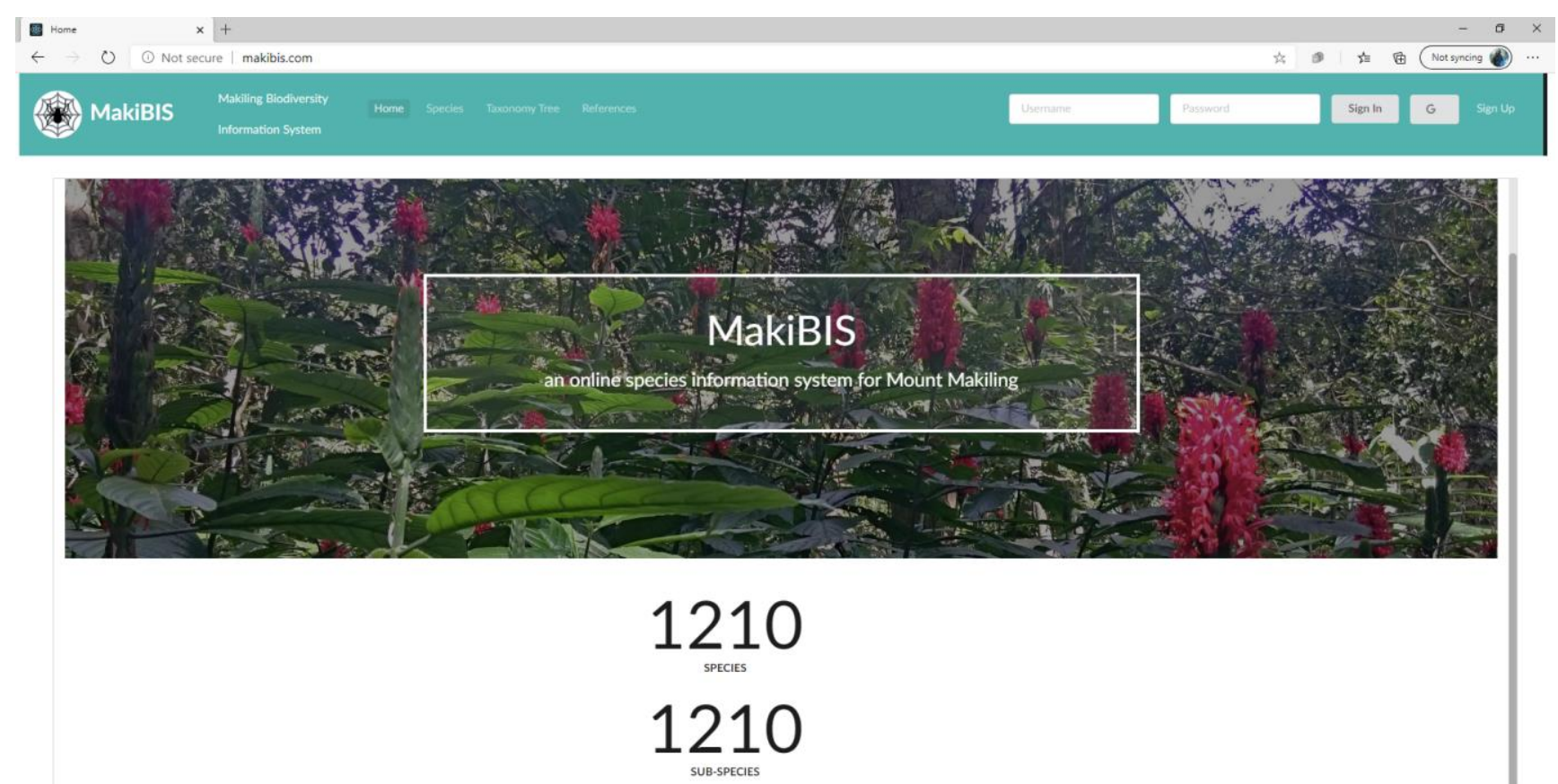

Figure 1. Landing page of MakiBIS 


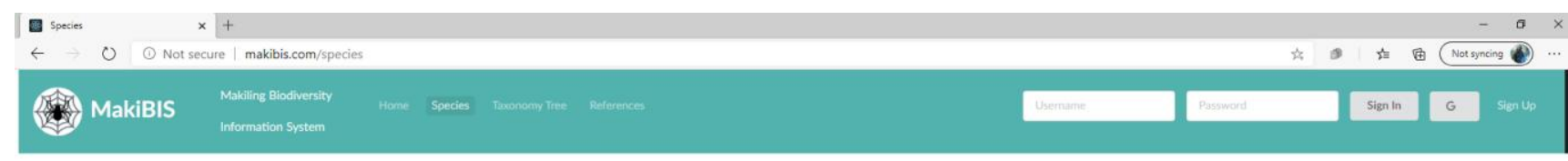

\section{Species}

a Search by Searchtor species a

\begin{tabular}{|c|c|c|c|c|c|c|c|}
\hline Profile & Sclentific Name $\stackrel{-}{-}$ & Family $=$ & Order $\rightarrow$ & Class $\neq$ & Phylum $\neq$ & Kingdom $\neq$ & Domsin $₹$ \\
\hline 国 & Mussaenda ervthrophylla & Rubiaccas & Rubiales & Magnoliopsida & Magnoliophyta & Plantac & Eukarya \\
\hline 요 & Psychotria membranifolia & Rubiacease & Rubiales & Magnoliopsida & Magnolioptyta & Plantae & Eukarya \\
\hline (4⿴囗十) & Cordia gerascanthoides & Boraginacease & Lamiales & Magnoliopsida & Magnoliophyta & Plantac & Eukarya \\
\hline 国 & Alstonia scholaris & Apocynaceae & Gentianales & Magnoliopsida & Magnoliophyta & Plantac & Eukarya \\
\hline 国 & Thevetia pervviana & Apocynaceae & Gentianales & Magnoliopsida & Magnoliophyta & Plantae & Eukarya \\
\hline 国 & Callicarpa erioclona & Verbenaceac & Lamiales & Magnoliopsida & Magnoliophyta & Plantac & Eukarya \\
\hline 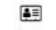 & Thunbergia alata & Acanthacease & Scrophulariales & Magnoliopsida & Magnoliophyta & Plantae & Eukarya \\
\hline (4⿴囗十) & Adenostemma lavenia & Asteracese & Asterales & Magnoliopsida & Magnoliophyta & Plantac & Eukarya \\
\hline 国 & Plumbago auriculata & Plumbaginaceace & Plumbaginales & Magnoliopsida & Magnolioptyta & Plantae & Eukarya \\
\hline \multirow[t]{2}{*}{4} & Jacranda mimosifolia & Bignoniaceae & Scrophulariales & Magnoliopsida & Magnoliophyta & Plantae & Eukarya \\
\hline & & 3 & 5 & 8 & 10 & & \\
\hline
\end{tabular}

Figure 2. Species list
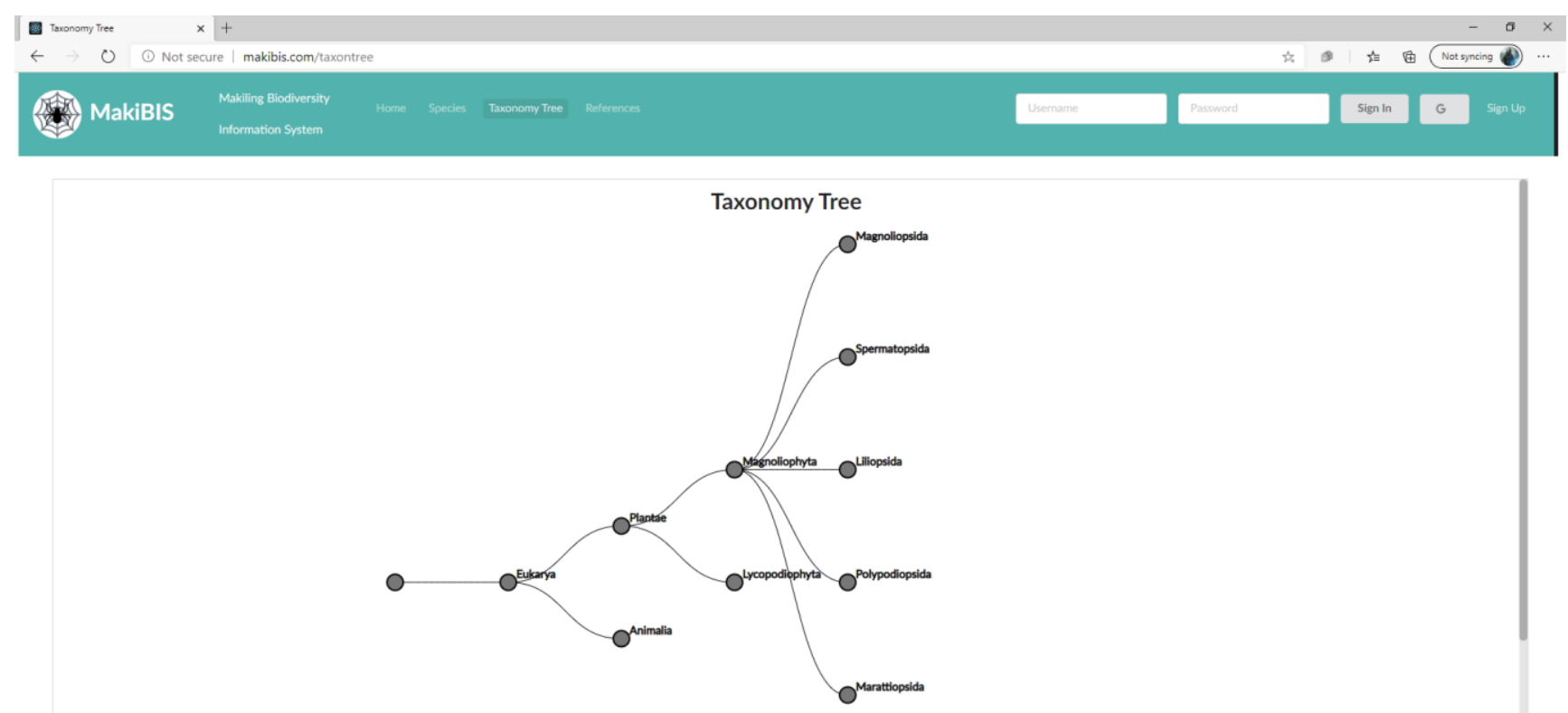

Figure 3. Taxonomic tree

The Species link on the landing page leads the user to the Species List page (Figure 2). This lists all the species encoded in the system. Clicking on the icon found at the leftmost section of each row directs the user to the Species Profile Page of the selected species.
The Taxonomy Tree (Figure 3) is another way of viewing the species encoded in MakiBIS. It displays a visualization of the taxonomic hierarchy of the species found in the system. 


\section{Database updates}

MakiBIS 2.0 still uses MariaDB for its database. Tables such as domain, kingdom, phylum, class, order, family, and genus were compressed to a single species table, reducing the number of tables from 27 down to 19. Several data types were also revised to facilitate better memory management, and some tables and attributes were also renamed for better readability.

\section{Data summary of species recorded in MakiBIS} Biodiversity database

The MakiBIS 2.0 database contains information about floral and faunal species found in Mt. Makiling. Currently, 1,697 plant species, 109 avian species, 30 mammals species, 17 amphibian species, 19 reptiles, and 17 fish species are encoded in the MakiBIS database. The main references for the floral list and their botanical description are the Vascular flora of Mount Makiling and vicinity (Luzon: Philippines) Parts 1, 2, 3, and 4 published by
Pancho and Gruezo (2006, 2009, 2012). For the listing of fauna, the main reference is Ecology and Distribution of Vertebrate Fauna of Mount Makiling Forest Reserve by Gonzales and Dans (1997). Information on the distribution, habitat, endemism, conservation status, economic use, and other related information was gathered from various journal articles, reports, and web bases. Spreadsheet files (Fig.4) were used to consolidate this information from various references to develop a database. The spreadsheet served as a raw file format that was imported into MakiBIS 2.0.

Fauna

Figure 5 shows that among the vertebrate fauna encoded in the MakiBIS 2.0 database, the dominant group is the Avian (56.8\%). This is followed by mammals (15\%), reptiles (9.9\%), and amphibians (8.9\%). Fishes (8.9\%) were also recorded in the stream and rivers in Mt Makiling.
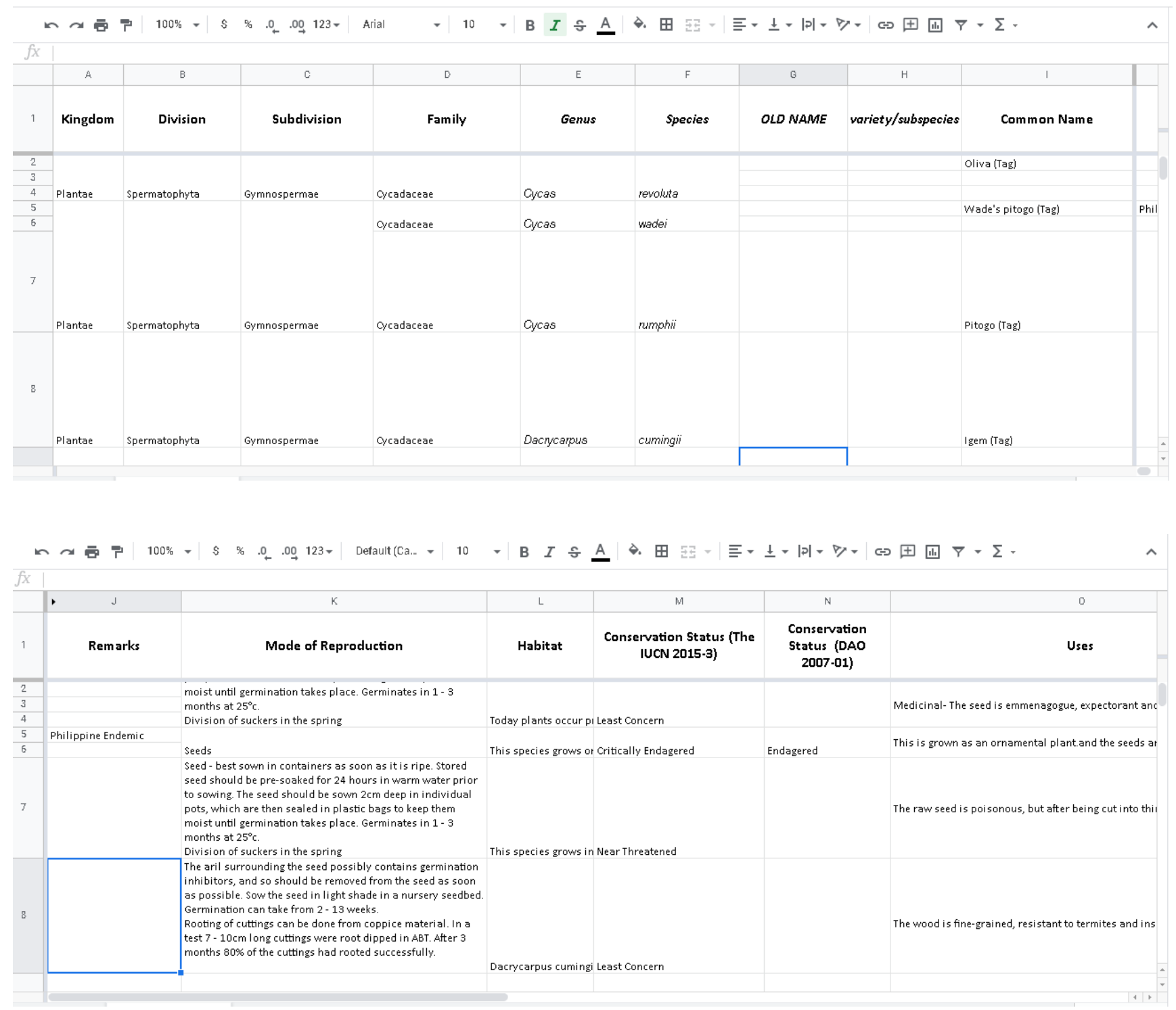

Figure 4. Spreadsheets for MakiBIS database 


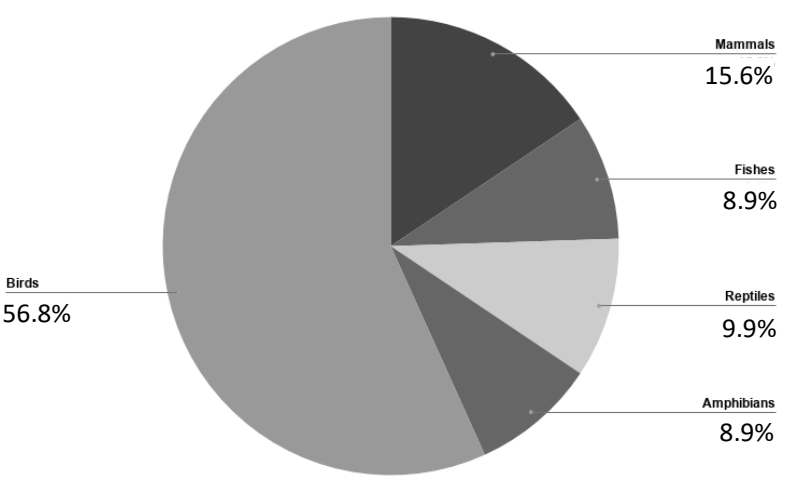

Figure 5. MakiBIS species composition of fauna diversity recorded from Mt. Makiling, Philippines

A total of 109 Avian species belonging to 44 families were sighted in Mt. Makiling (Table 1). The MakiBIS 2.0 database contains a record of 19 species of reptiles and 17 species of amphibians belonging to seven and three families, respectively. As for the mammals, 30 species belonging to nine families are documented in the database. Aquatic fauna was recorded from the freshwater ecosystems of three major watersheds in Mt. Makiling. An updated study of Paller et al. (2011) revealed that there are nine new recorded fish species compared to the earlier study of Herre (1953). Currently, the MakiBIS 2.0 database contains records of 17 fish species (Table 1).

de Guia and Quibod (2014) recorded three introduced species (Mus musculus, Rattus exulans, and R. tanezumi) of small non-volant mammals from mid-montane forest and lower areas of Mt. Makiling. The list of endemic and introduced species recorded in various elevational gradients of Mt. Makiling includes a new record for Apomys microdon and a possible new species assigned as Apomys sp. (de Guia et al. 2011). Records of Chrotomys mindorensis at the lowest elevation were based on interviews.

Alcala et al. (1997) reported in their study on amphibians that human habitation is associated with the open fields and ponds which are the habitat of Rana limnocharis, Rana cancrivora, and Ooeidozyga laevis. In fact, their habitat is mostly adapted to man-made aquatic structures. For instance, the Kalou labaleata and Kaloula picta, both from the family Microhylidae, usually live near human habitations, even though they may climb low vegetation or penetrate forests. Meanwhile, there are three species that are found to represent the family
Rhacophoridae. One of them is the Rhacophorous pardalis, a species that has been considered rare. Another ubiquitous and adaptable species from the aforementioned family is the Polypedates leucomystax. The last species found is the Philautus surdus, which usually occupies aerial microhabitats like aerial ferns, moss growing on trees, and climbing Pandanus. Thus, they are abundant in the moist middle and high latitudes (600-1,160 masl) or cooler parts of Mt. Makiling (Alcala et al. 1997).

\section{Endemism and residency status}

Mt. Makiling fauna exhibits a high rate of endemism (Figure 6). Leading the rate are the reptiles with 12 endemic species out of the overall number of 19 species (63\%). Avian group has 51 endemic species out of 109 recorded species (47\%). Mammals have $40 \%$ endemism with 12 endemic species out of a total of 30 reported species, while seven amphibians are endemic in Mt. Makiling out of 17 species (12\%).

A great majority of fishes recorded in Mt Makiling are introduced species (Figure 6). There are 17 fish species recorded in Mt. Makiling database. As per Herre's Philippine Expeditions records (1927, 1931, 1936-1937, and 1940-1941), there were eleven species, of which seven are native and four are endemic, in Molawin Creek. The four endemic fish species recorded were Nomorhamphus vivipara, Nomorhamphus pectoralis, Zenarchopterus philippinus, and Gulaphallus mirabilis (Herre 1953).

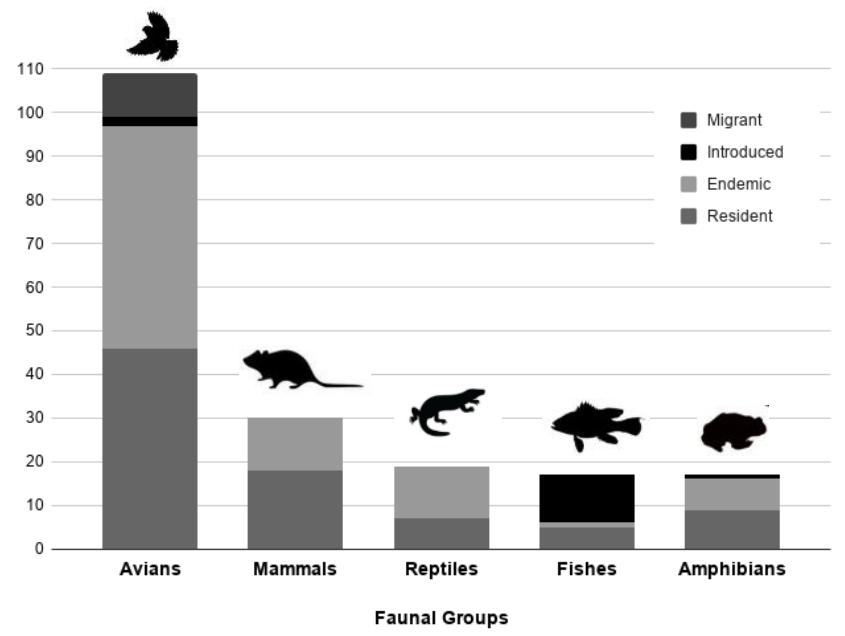

Figure 6. Faunal endemism and residency status in MakiBIS database

Table 1. Number of species, genus and families of vertebrate fauna recorded in Mt. Makiling, Philippines

\begin{tabular}{|c|c|c|c|c|c|c|}
\hline & \multicolumn{6}{|c|}{ Faunal groups } \\
\hline & Mammal & Avian & Reptiles & Amphibians & Fishes & Total \\
\hline Family & 9 & 44 & 7 & 3 & 10 & 73 \\
\hline Genus & 22 & 79 & 15 & 8 & 14 & 138 \\
\hline Species & 30 & 109 & 19 & 17 & 17 & 192 \\
\hline
\end{tabular}


Meanwhile, a recent study on freshwater fish species in the MFR watersheds, namely, Molawin Creek, Dampalit Falls, and Cambantoc River was conducted by Paller et al. (2011). The results of their survey showed that the MFR watersheds have abundant and diverse freshwater fish. A total of 4,920 individuals of 16 species, coming from 13 genera and 10 families, were recorded from the study sites. The only endemic species found is Leiopothera ponplumbeus. The five native species recorded were Glossogo biusgiuris, Glossogo biuscelebius, Hippichthys heptagonus, Giuris margaritacea, and Rhinogobius sp. Further, the 10 introduced species recorded were Pterygoplichthys disjunctivus, Clarias batrachus, Sarotherodon melanotheron, Oreochromis niloticus, Channa striata, Xiphophorus helleri, Poecilia latippina, Poecilia reticulata, Trichopodus trichopterus, and Trichopodus pectoralis.

The native species found to be common in all the MFR watersheds are the Rock goby (Glossogobius celebius) and Snakehead gudgeon (Giuris margaritacea). The computed similarity index of the MFR watersheds is $72 \%$. Meanwhile, the diversity index for Molawin Creek, Dampalit Falls, and Cambantoc River are 1.15, 1.12, and 0.85, respectively. Species richness revealed that in Molawin Creek, there are 12 species, of which four are native. On the other hand, Dampalit Falls has 12 species, of which five are native and one is endemic. Two out of the nine species found in Cambantoc River are native (Paller et al. 2011).

Nine out of 12 species in Molawin Creek found by Paller et al. (2011) have not yet been recorded by Herre during his many previous expeditions in the country. Out of the twelve species recorded earlier by Herre, there were only three introduced species found by Paller et al. (2011). However, they added eight new introduced species as part of the latest record. Further, Hippichthys heptagonus, a native species, which was not previously recorded from Molawin Creek, was interestingly found in certain portions of the river. This native species was also seen in the Dampalit River but not in the Cambantoc River. Since the occurrence of introduced species threatens the stability of native ecosystems, both the native and introduced species present in the areas were documented. Introduced species such as Nile tilapia (Oreochromis niloticus) and Janitor fish (Pterygoplichthys disjunctivus) are known to prey on the eggs and juveniles of native species while competing for available food and space (Paller et al. 2011). However, Hippichthys heptagonus and Glossogobius celebius, as diminutive or extinction-prone species, found the watersheds, particularly those with least human interventions, as sanctuary.

Resident and endemic species comprise the majority of faunal diversity in MakiBIS 2.0 database. Currently, the resident species accounted for $47 \%$ (90 species) of the total number of 192 faunal species, including 46 avian species, 18 mammal species, 7 reptiles, 14 amphibians, and 5 fish species (Figure 6). This is followed by the endemic species with a total of 78 species. The mammals and reptiles in Mt. Makiling are composed only of resident and endemic species (See Table S1 for the listing of endemic faunal species). Moreover, the coexistence of an exotic species, Bufo marinus, with native amphibians has no significant ecological effects (Alcala et al. 1997). The cane toad (Bufo marinus) is the sole introduced amphibian species in Mt. Makiling (Alcala et al. 1997).

It is only the avian population that includes migratory species that seasonally settle in Mt. Makiling (Figure 6). The changes in the rainfall, temperature, and spatiotemporal microhabitat environments are identified to affect the food availability for birds. Thus, the variation in the composition and structure of vegetation also changes the composition of birds. This particularly happens in disturbed habitats prone to vegetation loss. The appropriate conservation and management of the trophic structure at this lower elevation will provide different food for birds.

\section{Conservation status}

The main reference for this section of the MakiBIS 2.0 database is the IUCN Red Data List. From the list, there are three faunal species in the MakiBIS 2.0 database that fall under the Threatened category. A significant decrease in the population size of a species is the main reason for its inclusion in the category. The two mammal species included in the list are the Philippine warty pig (Sus philippinensis) and the elusive Phillippine brown deer (Cervus marianus). The lone reptile species listed as Vulnerable is the spot-bellied short-headed snake (Oligodon modestum).

Gonzalez and Dans (1997) further reported that five bird species including the Philippine forest kingfisher (Ceyx melanurus), golden-crowned tree-babbler (Stachyris dennistouni), green-faced parrot-finch (Erythruraviridifacies), the Philippine eagle (Pithecophaga jefferyi), and the Rufous hornbill (Buceros hydrocorax) were last seen in the mountain in 1971. Among the extirpated species that belong to the mammal group known for their exclusive endemicity in Mt. Makiling includes the Luzon short-nosed rat (Tryphomys adustus), lowland striped shrew rat (Chrotomys mindorensis), and Luzon broad toothed rat (Abdtomys latidens). These small mammals are highly susceptible to changes in their environment that further aggravates their dwindling population. As for the reptile species, the lone extirpated species in Mt. Makiling is the burrowing snake (Oxyhaddium leporinum). The remaining faunal species in the MakiBIS 2.0 database are classified into either as None Threatened, Near-Threatened, or Least Concern category.

\section{Flora}

Botanical diversity comprises the bulk of the data recorded in MakiBIS 2.0 database. Updated listing of the system harbors information of 1,697 floral species from 190 families. In terms of growth habit, more than half of the species encoded in the MakiBIS database are shrubs and small trees $(54.2 \%)$, while taller trees compose about $22.5 \%$. Other plant species are climbers and creepers $(12.9 \%)$, grasses and sedges $(7.5 \%)$, and palms and palmlike trees $(2.2 \%)$.

Among the tree species, the family Moraceae is greatly represented in the MakiBIS database with 40 tree species (Figure 7.A). Other well-represented families are Dipterocarpaceae, Meliaceae, and Annonaceae. Climbers 
and creepers such as epiphytes, lianas, vines, and stoloniferous plants constitute some 219 species in the database with Legumes (Papilionaceae) which make up the bulk for this plant group (Figure 7.B). MakiBIS 2.0 also shows that the dominant undershrub vegetation is comprised of 919 species with Spurges (Euphorbiaceae) being the family with the most number of species (83 species) (Figure 7.C). Other notable plant groups are the Cycads (Cycadaceae), Palms (Arecaceae) (37 species), grasses, and sedges such as sedges (Cyperaceae) and bamboos (Poaceae) that have 128 species. Other forms of plant habit are the aquatics such as the Hyacinths (Pontederiaceae), Watermilfoils (Halogaceae), Naiads (Najadaceae), and the Frog-bits (Hydrocharitaceae) that take up a total of 11 species in the MakiBIS database and the Rafflesia (Rafflesiaceae) as the sole plant in its habitat type. Overall, the shrubs and small trees make up more than half $(54 \%)$ of the vegetation in Mt. Makiling, followed by the trees making up about $22 \%$ and the climbers and creepers that constitute about $13 \%$ (Figure 7.D).

\section{Habitat}

Tropical rainforests like Mt. Makiling have diverse ecosystems. It provides an environment for the development of different vegetation types along its elevational gradient: the upper montane rain forest $(>1000$ masl), lower montane forest (>750 masl), lowland evergreen forest (100-500 masl), and grassland vegetation (<100 masl) (Fernando et al. 2008). Analysis of the habitat information in MakiBIS 2.0 showed that there are 434 plant species from the upper montane rainforest, 110 species from the lower montane forest, 474 species from lowland evergreen forest, and 28 species from grassland vegetation. As for the other floral species, there was no specified elevation or habitat encoded in the database. Plants can be effectively used in determining the altitudinal zonation of mountains since certain plant species grow abundantly under specific climatic factors like humidity and temperature which vary with elevational gradient. On the other hand, there are floral species that cover an extensive range of habitats.

\section{Endemicity}

Currently, MakiBIS 2.0 holds information on 301 endemic Angiosperm and one endemic Gymnosperm plant species in Mt. Makiling (Table 2). Endemic species represent $18 \%$ of the 1,697 floral species currently listed in the database. Floral diversity of Mt. Makiling represents species belonging to various geographic endemicities that are exclusive to Luzon (79 species), Luzon and Visayas (32 species), and Luzon and Mindanao (18 species), and with the rest being Philippine endemic. The endemic Gymnosperms species in Mt. Makiling is Wade's pitogo (Cycas wadei).

There are 190 plant families in Mt. Makiling that have endemic species. Among these, Annonaceae has the most number of endemics with 24 species out of its 38 species recorded in Mt. Makiling (see Table S2 for the listing of endemic species). Malabrigo et al. (2016) identified about 155 tree species, and of this number, 148 are indigenous to the country with 47 endemics or $30 \%$ endemism.

\section{Economic use}

Data on the various uses of plants listed in the database represent the known actual economic use and the potentiality that it may serve. The economic uses of floral species in Mt. Makiling are categorized as either food, medicinal, construction, source of raw materials, and ornamental.

(i). Medicinal: These are the plants that have proven values for modern medicine or known traditional herbal medicine. MakiBIS 2.0 holds information on 393 plant species with medicinal attributes;

(ii). Edible plants: These are the plants utilized and known to have edible parts. Both highly cultivated or locally consumed, Mt. Makiling harbors 249 plant species of edible plants;

(iii). Construction/ building materials: Plants that are harvested for its wood quality that is best suited for carpentry, building material, furniture making, and light construction use. Mt. Makiling is known to be a commercial source of timber until regulations were imposed protecting its 140 timber species;

(iv). Raw materials: These are the non-wood materials extracted from plants. MakiBIS 2.0 holds information on 115 species of plants that are utilized as a source of fiber, resin, dye, pulp and paper materials, tannins, and gums;

(v). Ornamentals: Mt. Makiling is also a haven for plants that are used for its decorative properties. There are 67 plant species in the Makiling database known to be harvested for landscaping, garden plants, and other horticultural purposes;

(vi). Others: These are plants that are utilized as reforestation species, soil erosion measures, green manure, and cultural purposes. There are at least 58 species of plants in Mt. Making that serve these purposes.

\section{Conservation status}

MakiBIS 2.0 database provides information about the conservation status of flora of Mt. Makiling. This information was collected from IUCN and the local DENR Administrative Order (DAO) 2007-01.

Table 2. Endemism per plant group in MakiBIS

\begin{tabular}{llll}
\hline Plant group & Family & Species & Endemicity $(\%)$ \\
\hline Gymnosperm & 6 & 14 & $1(7 \%)$ \\
Angiosperm & 184 & 1,683 & $301(17.9 \%)$ \\
Total & 190 & 1,697 & 302 \\
\hline
\end{tabular}

Table 3. Number of species under Threatened categories following DAO and IUCN

\begin{tabular}{lcc}
\hline \multicolumn{1}{c}{ Threatened category } & DAO 2007- & IUCN \\
& 01 & $\mathbf{2 0 1 5 - 3}$ \\
\hline VU (Vulnerable) & 25 & 45 \\
EN (Endangered) & 21 & 8 \\
CN (Critically Endangered) & 11 & 19 \\
OTS (Other Threatened Species) & 13 & - \\
Total & 70 & 72 \\
\hline
\end{tabular}


Trees

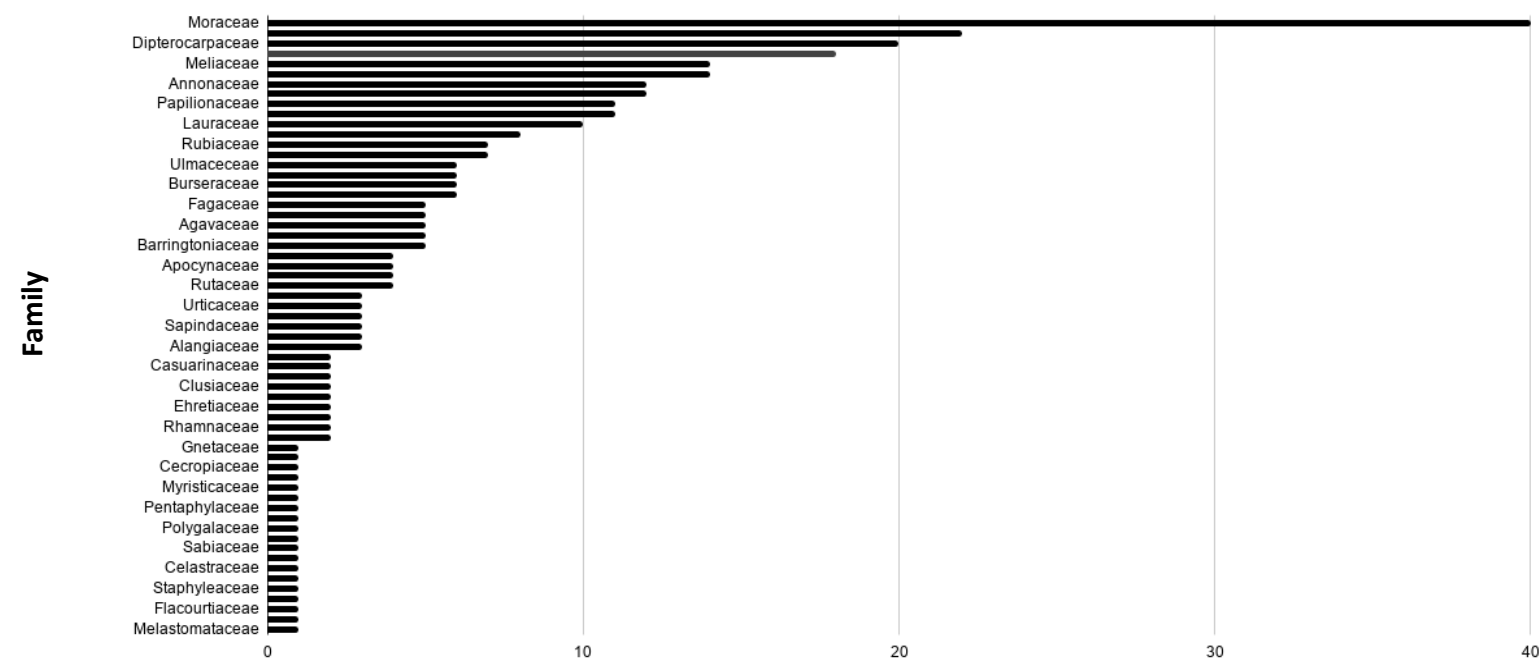

Number of species

A

Climbers \& creepers

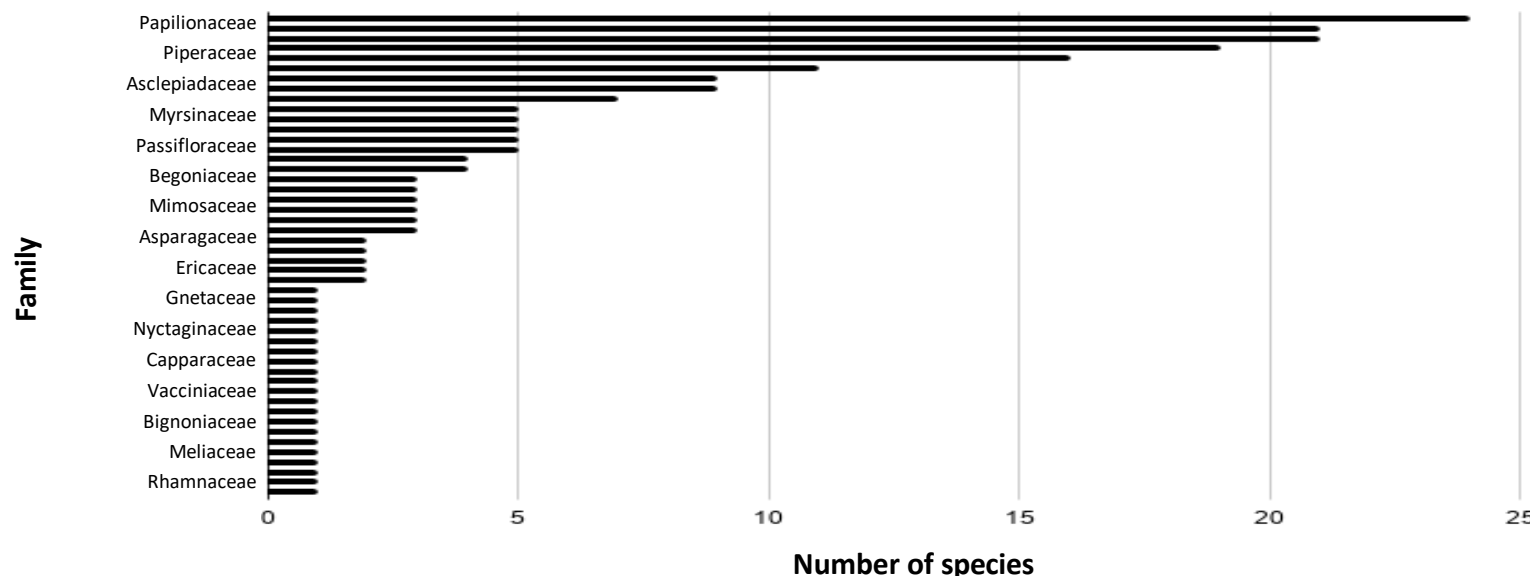

B

Shrubs \& small trees

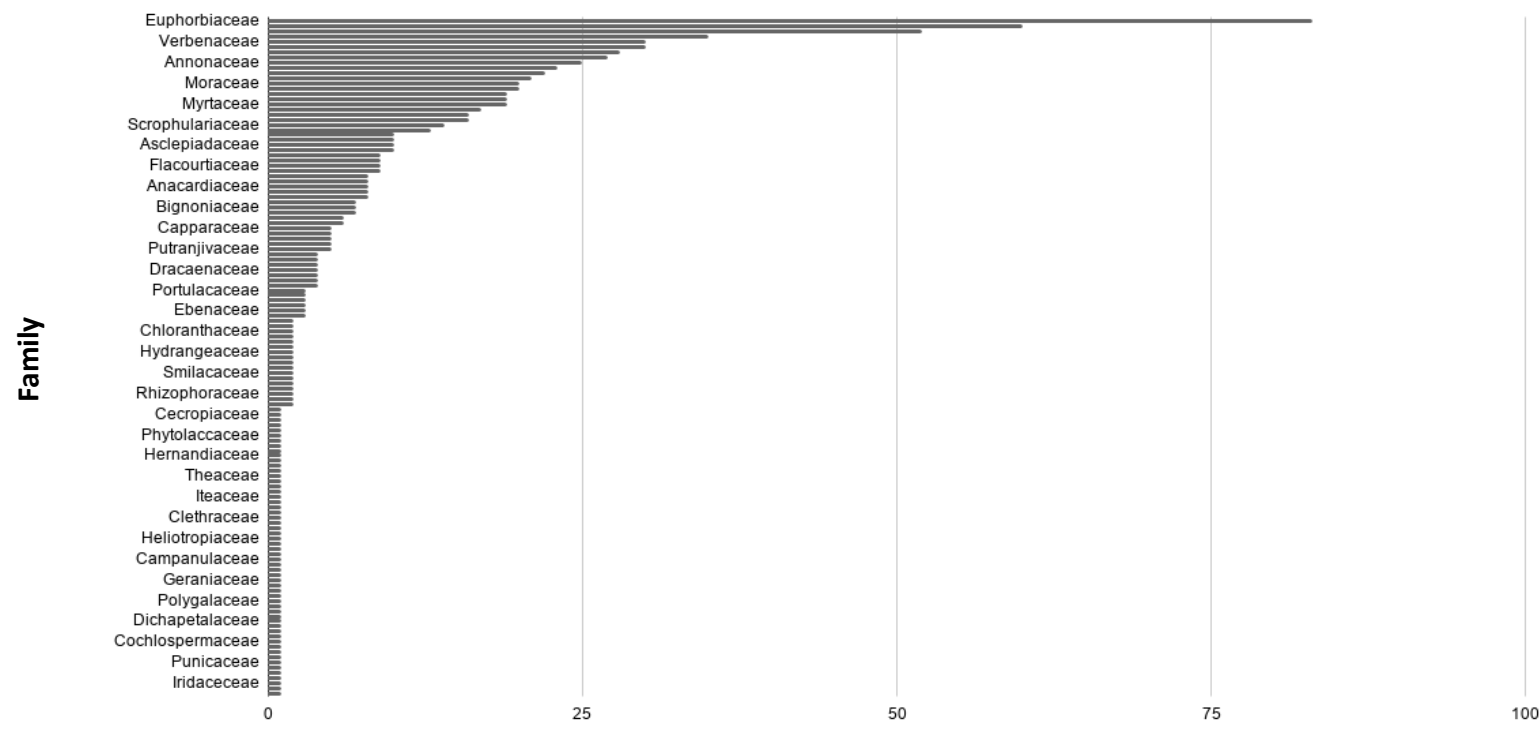

Number of species 


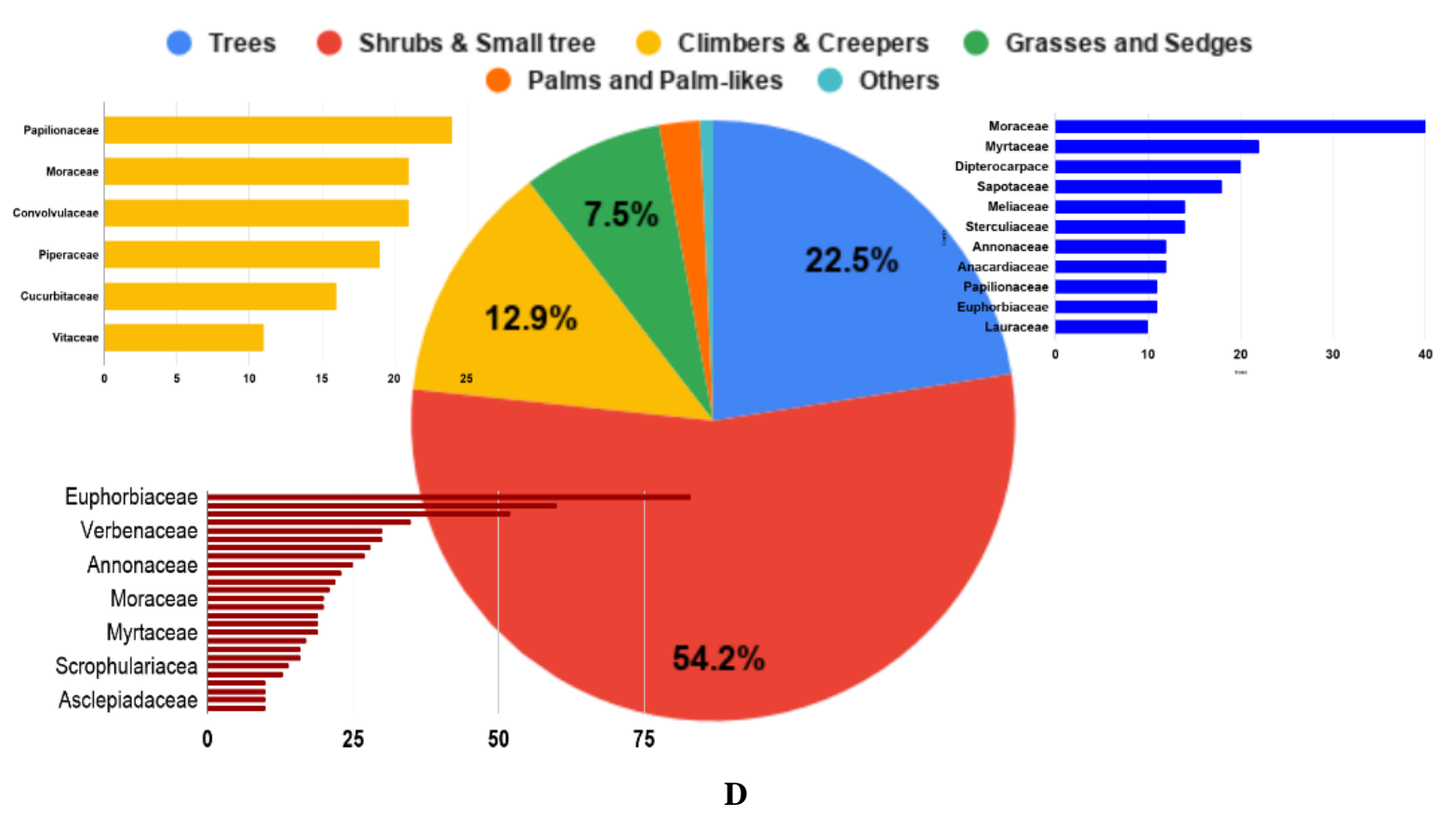

Figure 7. Floral families and the number of species according to plant habits (A) Trees, (B) Climbers and Creepers, (C) Shrubs and small trees, and (D) all plant forms that are encoded in the MakiBIS 2.0

A total of 70 threatened floral species are present in Mt. Makiling based on DAO 2007-01 category while 72 species are threatened based on the IUCN threatened category (Table 3). There are 40 plant families that have threatened species, and among those, Dipterocarpaceae has the most number (16 species) of threatened species in Mt. Makiling. Dipterocarpaceae are hardwood tree species that used to be logged for construction purposes. The discrepancy of the result from this evaluation is merely based on the definition of the parameters for each category accounted by the evaluators.

In the MFR, Malabrigo et al. (2016) and Castillo et al. (2018) reported that around 29 species are either in the Philippine Red List or the IUCN Red List of Threatened Species. Also in the list are the six critically endangered premium timber species such as Makaasim (Syzygium nitidum), Kamagong (Diospyros discolor), Narra (Pterocarpus indicus), Bagtikan (Parashorea malaanonan), Guijo (Shoreaguiso), and White lauan (Shorea contorta).

At present, Mt. Makiling forests are threatened by outlawed conversion of forest lands into agricultural lands and informal settlements. The areas of informal settlements are continuously expanding. In 2003, only 280 households were in Mt. Makiling forest. But currently, there are already around 1,225 settlers in the area (Paller et al. 2011). These settlers are on the slopes that are not that steep. Furthermore, agricultural farms, agroforestry, grasslands, leased areas, and plantations are within the forest area. The analyses of 2002 satellite images by Bantayan et al. (2008) revealed forest disturbance in the northern and western parts while agroforestry systems were most evident in the south-eastern part of the MFR. The changes in the MFR's landscape were evaluated by Combalicer et al. (2011) using ISOCLUST method in three different periods of remotely sensed data sets. Based on the recent remotely sensed data sets, the analysis showed that the spatial distribution of several land-cover categories caused gain and loss of forests. In fact, between 1993 and 2002, the evaluation revealed an increase in agroforestry areas and a decrease in forest areas.

However, agroforestry practices give ecological contributions to the farmers in the watershed areas. In particular, the farming system contributes to the conservation of biodiversity and carbon sequestration of woody perennials (Baliton et al. 2017). This is based on the study in Molawin-Dampalit Sub-watershed in MFR and the Way Betung Watershed in Indonesia. This study included interviews with 106 and 261 farmers and evaluation of 27 and 14 agroforestry plots for carbon stock estimation and biodiversity evaluation, respectively. The results recommended to intensify and heighten the promotion of agroforestry systems inappropriate parts of the watershed areas to contribute to the ecological balance. Agroforestry should be an important part of all the strategies toward ecological restoration with farmers as probable partners.

Today, Mt. Makiling is a landscape of land patches that include plantations, agricultural lands, agroforestry systems and residual forests. It may also have degraded land areas (Combalicer et al. 2011). Only a certain part of Mt. Makiling is a closed canopy forest while the other parts were used for establishing the National Arts Center, Boy Scouts of the Philippines, and UPLB College of Forestry. It also has ecotourism and recreational areas such as Mudspring, Makiling Botanic Garden, Pookni Maria 
Makiling, Flat Rocks, and other beautiful sights. Also, Mt. Makiling forest is known for its lush forest and clean spring water. The forest invites the campers and hikers because of these attractions and also its proximity to urban regions in Metro Manila and Southern Tagalog (de Guia and Quibod 2014). However, these visitors usually leave tracks and garbage, thus there are marks of vandalism and pollution in the forest. The study by Abraham et al. (2010) in the crater area of Mt. Makiling showed that the forest is jeopardized by detrimental human activities like negligent camping and devastation of forest resources including wildlife poaching and illegal cutting of trees. It is also revealed that ferns are susceptible to environmental changes, hence, their abundance and distribution across different land-use types in Mt. Makiling can enlighten the government to formulate proper fern conservation and management strategies in the forest (Alcala et al. 2019).

The introduced rodents rely mainly on human habitats for shelter, food, and water. Therefore, they are usually living close to humans (Tung et al. 2012). Some of the areas in the mountain are also occupied by upland settlers (de Guia and Quibod 2014). There are households up to the Agila base of Mt. Makiling at 525 masl. However, the non-native rodents use the forest resources up to the midmontane forest (de Guia and Quibod 2014).

The different anthropogenic activities caused changes in the distribution and richness of species within the forest. For instance, some of the reptiles and amphibians can survive in secondary forest, but many species only live in primary forest habitats. Therefore, these species might not last long in disturbed areas. They can also move to other places where they can have better survival. Also, some of the informal settlers in the forest are practicing various illegal activities like hunting and bird trading (Paller et al. 2011). It is necessary, however, to highlight that a more diverse source of substrate, particularly the woody debris, is offered by an undisturbed site. Hence, undisturbed forest should be sustainably managed by preserving deadwood of all sizes and decay stages that maintain wood-inhabiting fungal diversity (Gates et al. 2011).

Since Mt. Makiling is under the management of UPLB, its Administration in cooperation with the Institute of Forest Management is developing plans and implementing measures to control the present situation towards conservation of biodiversity in Mt. Makiling. Participatory consultation meetings and biodiversity conservation information awareness campaigns are being conducted with upland communities living inside the forest. The Makiling Center for Mountain Ecosystems (MCME) of the College of Forestry and Natural Resources, UPLB is closely monitoring and controlling the number of hikers and tourists visiting the forest reserve. Collection of biodiversity specimens and samples from the reserve are strictly prohibited by the university. Forest rangers of MCME are regularly scouting the MFR for illegal settlers and violators of the conservation and protection measures of the forest reserve. Violators face legal actions by the university.

As web technology, database technology, hardware technology, and computer software improvement, the information system also develops. The information system has significantly improved the data management standardization, level of information use, and speed of information dissemination. It has also led to a lower cost, higher efficiency, and better impact on management. Its use for management, storage, use, and exchange of biodiversity information is the outcome of adapting to the current information age and usually the better option to strengthen the use and protection of biodiversity (Dai 2012).

The information system structure from the data input, statistics, printing, query, document management, and system maintenance which addressed the general needs for biodiversity information has constantly advanced and expanded (Long and Yang 2005). It now adds more modules like habitat monitoring, animal and plant distribution, and landscape structure. The functional integration of the information system can give wideranging support to the decision-makers (Xiong et al. 2003; $\mathrm{Yi}$ and Wang 2009). Generally, the biodiversity information system is advancing toward an integrated and multifunctional application.

To conclude, MakiBIS 2.0 features a faster and more responsive user interface, compressed and optimized database tables, and backend functions written using NodeJS. It currently holds taxonomic information, botanical description, habitat, endemism, economic use, and conservation status of 1,697 floral and 192 faunal species. Consolidating biodiversity and ecological information on the flora and fauna of Mt. Makiling from various sources into a database is a crucial preliminary step towards the overall analysis of the state of biodiversity in the forest reserve. The database was analyzed for trends and patterns, economic use, endemicity, and threatened categories which are useful in formulating different participatory strategies for protection and rehabilitation of biodiversity in Mt. Makiling.

The UPLB administration, in cooperation with the Institute of Forest Management, is developing plans and implementing measures to control the present situation towards the conservation of biodiversity in Mt. Makiling. Participatory consultation meetings and biodiversity conservation information awareness campaigns are being conducted with upland communities living inside the forest. The Makiling Center for Mountain Ecosystems (MCME) of the College of Forestry and Natural Resources, UPLB is closely monitoring and controlling the number of hikers and tourists visiting the forest reserve. Collection of biodiversity specimens and samples from the reserve are strictly prohibited by the university. Forest rangers of MCME are regularly scouting the MFR for illegal settlers and violators of the conservation and protection measures of the forest reserve. Violators face legal actions by the university.

\section{ACKNOWLEDGEMENTS}

The work described in this paper is funded by the University of the Philippines Enhanced Creative Work and Research Grant (ECWRG 2018-02-15). 


\section{REFERENCES}

Abraham ERG, Gonzalez JCT, Castillo ML, LitIL Jr., Fernando ES. 2010. Forest cover and biodiversity profile of the crater area of $\mathrm{Mt}$. Makiling, Luzon, Philippines. Asia Life Sci Suppl 4: 48-82.

Alcala AA, Angeles MDD, Buot IE Jr. 2019. Fern species diversity across various land use types of Mt. Makiling, Luzon Island, Philippines. Biodiversitas 20 (9): 2437-2445.

Alcala AC, Brown WB. 1998. Philippine Amphibians: An Illustrated Field Guide. Bookmark, Inc. Makati City.

Alcala AC, Brown WC. 1998. Philippine Amphibians: An Illustrated Field Guide. Bookmark, Inc. Makati City.

Alcala AC, Custudio CC, Diesmos AC, Gonzales JCT. 1997. List of amphibians of Mt. Makiling, Laguna, Philippines, with notes on their population status. Sylvatrop: Techn J Philippine Ecosyst Nat Resour 5: 65-71.

Alvarez JD, Lit IL Jr., Alviola PA. 2015. Bat flies Diptera: Nycteribiidae from Mount Makiling, Luzon Island: New host and distribution records, with a checklist of species found in the Philippines. Check List 11 (1), 1509

Baliton RS, Wulandari C, Landicho LD, Cabahug RED, Paelmo RF, Comia RA, Visco RG, Budiono P, Herwanti S, Rusita R, Castillo AKSA. 2017. Ecological services of agroforestry landscapes in selected watershed areas in the Philippines and Indonesia. Biotropia 24 (1): 71-84.

Bantayan NC, Abraham ERG, Fernando ES. 2008. Geodatabase development for forest restoration and biodiversity conservation in the Mt. Makiling Forest Reserve, Philippines. Philippine Agric Sci 9 14.

Biodiversity Conservation Society of the Philippines. 2020. Philippine Red List of Threatened fauna Part 1 - Vertebrates. Department of Environment and Natural Resources, Forest Management Bureau.

Caldecott JO. 1993. Opportunities for Biodiversity Management in the Makiling Forest Reserve, Philippines. ERMP.

Castillo ML, Castillo LA, Canceran MS, Gonzalvo KJP, Barua LD, Alegre AC, Barredo-Parducho VO, Gestiada EC, Breva RV, Bantayan NC. 2018. Distribution, diversity and spatial analysis of tree species in a long-term ecological research plot in Molawin-Dampalit Watershed, Mount Makiling Forest Reserve. Asian J Biodivers 9 (1) 12-36.

Combalicer MS, Kim D, Lee DK, Combalicer EA, Cruz RVO, Im S 2011. Changes in the forest landscape of Mt. Makiling forest reserve Philippines. For Sci Technol 7 (2): 60-67.

Conservation International. 2008. Biological diversity in the Philippines. https://editors.eol.org/eoearth/wiki/Biological_diversity_in_the_Phili ppines

Convention on Biological Diversity https://www.cbd.int/countries/profile/?country=ph

Dai XT. 2012. Research progress on biodiversity information system. 2012 International Conference on Computer Science and Service System, Nanjing. IEEE Computer Science. DOI 10.1109/CSSS.2012.81.

De Chavez ERC, De Lara AV. 2011. Diversity and spatial distribution patterns of macro land snails in Mount Makiling Forest Reserve, Philippines. Asia Life Sci 20 (1): 183-197

de Guia AP, Quibod MNR. 2014. Gut analysis of small non-volan mammals of Mt. Makiling, Luzon Island, Philippines. J Environ Sci Manag 17 (2): 63-68

Department of Environment and Natural Resources/United Nations Environment Program. DENR/UNEP. 1997. Philippine biodiversity: An assessment and action plan.

Department of Tourism - Department of Environment of Natural Resources (DOT - DENR). 2002. National ecotourism strategy.

Fabunan M, Gerardo M, Maguslog J, Salumbre R, Surquia J, Diesmos M. 2008. Comparative Study of Lizard Populations in Mt. Makiling, Laguna. [Dissertation]. University of Santo Tomas, Philippines.

Facebook Inc. 2020, October 9. React - A JavaScript library for building user interfaces. https://reactjs.org/

Fernando ES, Co LC, Lagunzad DA, Gruezo WSm, Barcelona JF, Madulid, DA, Zamora PM. 2008. Threatened plants of the Philippines: A preliminary. Asia Life Sci 3: 1-52.

Fernando ES, Sun BY, Suh MH, Kong HY, Koh KS. 2004. Flowering Plants and Ferns of Mt. Makiling. Seoul: ASEAN-Korea Environmental Cooperation Unit, Seoul National University, Korea.
Gates GM, Mohammed C, Wardlaw T, Ratkowsky DA, Davidson NJ. 2011. The ecology and diversity of wood-inhabiting macrofungi in a native Eucalyptus obliqua forest of southern Tasmania, Australia. Fungal Ecol 4 (1): 56-67.

Gonzalez JCT, Dans ATL. 1997. Ecology and distribution of vertebrate fauna of Mount Makiling Forest Reserve. The Conditions of Biodiversity Maintenance in Asia: The Policy Linkages between Environmental Conservation and Sustainable Development. EastWest Center, Hawaii.

Gonzalez JCT. 1997. Pictorial guide to Philippine endemic forest birds of Mount Makiling, Luzon Island, Philippines.

Heaney LR. 1986. Biogeography of mammals in SE Asia: estimates of rates of colonization, extinction and speciation. Biol J Linn Soci 28 (1-2): 127-165.

Herre AW. 1953. Checklist of Philippine fishes Vol. 20. US Government Printing Office. International Union for Conservation of Nature, Iucn Species Survival Commission, International Union for Conservation of Nature and Natural Resources. Species Survival Commission. 2001. IUCN Red List categories and criteria. IUCN.

IUCN. 2015. The IUCN Red List of Threatened Species. Version 2015-4. www.iucnredlist.org

Lapitan FRG, Magcale-Macandog DB, Raymundo MDS, dela Cruz AG. 2013. Makiling Biodiversity Information System MakiBIS: Development of an online species information system for Mount Makiling. J Nat Stud 12 (1): 1-11.

Long T, Yang L. 2005. National nature reserve biodiversity information system development. Computer Engineering, 31 (17): 205-207.

Macandog DM, Paller VGV, Cervancia CR, Buot IE, Raymundo AK, Dalmacio IF, Cuevas V, Torreta NK, Mendoza B, Hadsall AS, De Guia APO, Opulencia RB, Pagaduan D, Chávez ED, Nacorda OS, Dimalibot J, Lacaste AV, Lambio IAF, Lauan MCB, dela Cruyz CPP, Fernández D. 2012. Biodiversity assessment of Mt. Makiling Forest Reserve [Los Baños, Laguna, Philippines]. Bibliography.

Mallari NAD, Tabaranza BR. 2001. Key conservation sites in the Philippines: A Haribon foundation \& BirdLife International directory of important bird areas. Bookmark.

Nacua AE, Pacis HYM, Manalo JR, Soriano CJM, Tosoc NRN, Padirogao R, Clemente KJE, Deocaris CC. 2018. Macrofungal diversity in Mt. Makiling Forest Reserve, Laguna, Philippines: with floristic update on roadside samples in Makiling Botanic Gardens MBG. Biodiversitas 19 (4): 1579-1585.

Oliver W, Heaney L. 1997. Biodiversity and Conservation in the Philippines. In: Philippine Red Data Book. Bookmark and Wildlife Conservation Society of the Philippines, Makati City.

Ong, PS, Afuang LE, Rosell-Ambal RG. 2002. Philippine biodiversity conservation priorities: A second iteration of the national biodiversity strategy and action plan. Philippine Department of the Environment and Natural Resources, Quezon City.

Open JS Foundation. 2020. https://nodejs.org/en/about/

Paller VGV, Labatos BV, Lontoc BM, Matalog OE, Ocampo PP. 2011. Freshwater fish fauna in watersheds of Mt. Makiling forest reserve, Laguna, Philippines. Philippine J Sci 140 (2): 195-206.

Pancho JV, Gruezo WSm. 2006. Vascular Flora of Mount Makiling and Vicinity Luzon: Philippines, Part 2. National Academy of Science and Technology NAST Philippines, Department of Science and Technology, Bicutan, Taguig City and Institute of Biological Sciences, University of the Philippines Los Baños, College, Laguna, Philippines Publishers.

Pancho JV, Gruezo WSm. 2009. Vascular Flora of Mount Makiling and Vicinity Luzon: Philippines, Part 3. National Academy of Science and Technology NAST Philippines, Department of Science and Technology, Bicutan, Taguig City and Institute of Biological Sciences, University of the Philippines Los Baños, College, Laguna, Philippines Publishers.

Pancho JV, Gruezo WSm. 2012. Vascular Flora of Mount Makiling and Vicinity Luzon: Philippines, Part 4. National Academy of Science and Technology NAST Philippines, Department of Science and Technology, Bicutan, Taguig City and Institute of Biological Sciences, University of the Philippines Los Baños, College, Laguna, Philippines Publishers.

Pancho JV. 1973. Mt. Makiling as a station for biological research. Philipp Agric 57: 21-33.

Pancho JV. 1983. Vascular Flora of Mount Makiling and Vicinity Luzon: Philippines, Part 1. Kalikasan, Philippine J Biol, Kalikasan Press, Manila. 
Panela S. 2014. The Philippines: Where 'megadiversity' meets mega deforestation. https://news.mongabay.com/2014/07/the-philippineswhere-megadiversity-meets-mega-deforestation/

Paquit J. 2017. Tree and macrofungal diversity of the two different habitat types in Mt. Makiling forest reserve. Int J Microbiol Mycol 10 (4): 18.

Parcon JA, Kim PM, Estorque J, Camacho MVC. 2020. Preliminary survey on the diversity and community assembly of macroinvertebrates along the Dakil river, University of the Philippines Laguna land grant, Paete, Laguna, Philippines. J Nat Stud 19 (1): 16-32.

Roy PS, Saran S, Ghosh S, Prasad N, Karnatak H, Talukdar G. 2002. Development of Biodiversity Information System for North East India Using Internet GIS. Symposium on Geospatial Theory, Processing and Applications. ISPRS. Ottawa https://citeseerx.ist.psu.edu/viewdoc/download?doi=10.1.1.97.5320\& ep=rep1\&type=pdf\#: :text=The $\% 20$ Biodiversity $\% 20$ Information $\% 20$
System $\% 20$ allows,in $\% 20$ identifying $\% 20$ areas $\% 20$ for $\% 20$ bioprospect ing.

Staley JT, Reysenbach AL. 2001. Biodiversity of Microbial Life: Foundation of Earth's Biosphere. Wiley- Liss, Inc, New York.

Taylor EH. 1922. Herpetological fauna of Mount Makiling. Philippine Agriculturist 51, 127-139.

Xiong Z, Zhao G, Chang Y. 2003. Plum mountain biodiversity information system. J Ecol 22 (3): 70-73.

$\mathrm{Xu}$ H. 1998. Some issues in establishing China's biodiversity information system. Rural Eco-Environ. 144: 11-15.

Yi D, Wang C. 2009. Based on the GIS Guangdong nature reserve information platform design and Implementation. Cent South For Surv Plann 283: 44-47.

Zhao B, Tang L, Wu Q. 2000. The establishment and applications of Shanghai biodiversity information system. Biodiversity 8 (2): 233237. 
Table S1. MakiBIS listing of endemic fauna in Mt Makiling, Philippines

\begin{tabular}{|c|c|c|c|}
\hline Phylum, Family & \multicolumn{2}{|l|}{ Scientific name } & \multirow[t]{2}{*}{ Remarks } \\
\hline \multicolumn{3}{|l|}{ Mammals } & \\
\hline \multirow[t]{2}{*}{ Pteropodidae } & Haplonycteris & fisheri & Endemic \\
\hline & Ptenochirus & jagorii & Endemic \\
\hline \multirow[t]{3}{*}{ Hipposideridae } & Hipposideros & obscurus & Endemic \\
\hline & Rhinolopus & subrufus & Endemic \\
\hline & Rhinolopus & Virgo & Endemic \\
\hline Vespertilionidae & Myotis & rufopictus & Endemic \\
\hline Crocidurinae & Crocidura & grayi & Endemic \\
\hline \multirow[t]{3}{*}{ Muridae } & Rattus & everetti & Endemic \\
\hline & Chrotomys & mindorensis & Endemic \\
\hline & Phloeomys & cumingi & Endemic \\
\hline Suidae & Sus & philippensis & Endemic \\
\hline Cervidae & Cervus & marianus & Endemic \\
\hline
\end{tabular}

Fishes

Terapontidae

Leiopotherapon plumbeus

Endemic

\section{Amphibians}

$\begin{array}{llll}\text { Ranidae } & \text { Rana } & \text { everetti } & \text { Endemic } \\ & \text { Rana } & \text { magna } & \text { Endemic } \\ \text { Rana } & \text { woodworthi } & \text { Endemic } \\ \text { Rhacophoridae } & \text { Platymantis } & \text { dorsalis } & \text { Endemic } \\ & \text { Platymantis } & \text { corrugatus } & \text { Endemic } \\ & \text { Platymantis } & \text { guentheri } & \text { Endemic } \\ & \text { Philautus } & \text { surdus } & \text { Endemic }\end{array}$

\section{Reptiles}

Gekkonidae

Scincidae

Agamidae
Colubridae
Elapidae

Viperidae

Birds

\begin{tabular}{llll}
$\begin{array}{l}\text { Accipitridae } \\
\text { Falconidae } \\
\text { Turnicidae }\end{array}$ & $\begin{array}{l}\text { Spilornis } \\
\text { Microheirax } \\
\text { Turnix }\end{array}$ & $\begin{array}{l}\text { holosphilus } \\
\text { erythrogenys } \\
\text { ocellata }\end{array}$ & $\begin{array}{l}\text { Endemic } \\
\text { Endemic } \\
\text { Endemic } \\
\text { (Luzon) }\end{array}$ \\
& $\begin{array}{l}\text { Macropygia } \\
\text { Gallicolumba }\end{array}$ & $\begin{array}{l}\text { tenuirostris } \\
\text { luzonica }\end{array}$ & $\begin{array}{l}\text { Endemic } \\
\text { Endemic } \\
\text { (Luzon) }\end{array}$ \\
& Phapitreron & $\begin{array}{l}\text { leucotis } \\
\text { amethystinus }\end{array}$ & $\begin{array}{l}\text { Endemic } \\
\text { Endemic } \\
\text { Phapitreron }\end{array}$ \\
& Ptilinopus & occipitalis & Endemic \\
\hline
\end{tabular}

Endemic

Endemic

Endemic

Endemic

Calliophis calligaster Endemic

Trimeresurus flavomaculatus Endemic

\begin{tabular}{|c|c|c|c|}
\hline \multirow[t]{7}{*}{ Psittacidae } & Bolbopsittacus & lunulatus & Endemic \\
\hline & Loriculus & philippensis & Endemic \\
\hline & Cacomantis & sepulcralis & Endemic \\
\hline & Centropus & viridis & Endemic \\
\hline & Centropus & unifurus & $\begin{array}{l}\text { Endemic } \\
\text { (Luzon) }\end{array}$ \\
\hline & Phaenicophaeus & cumingi & $\begin{array}{l}\text { Endemic } \\
\text { (Luzon) }\end{array}$ \\
\hline & Phaenicophaeus & superciolosus & Endemic \\
\hline \multirow[t]{2}{*}{ Strigidae } & Otus & megalotis & Endemic \\
\hline & Ninox & philippensis & Endemic \\
\hline Podargidae & Batrachostomus & septimus & Endemic \\
\hline \multirow[t]{2}{*}{ Apodidae } & Collocalia & troglodytes & Endemic \\
\hline & Collocalia & mearnsi & Endemic \\
\hline Trogonidae & Harpactes & ardens & Endemic \\
\hline Alcedinidae & Actenoides & lindsayi & Endemic \\
\hline Buccerotidae & Penelopides & manillae & $\begin{array}{l}\text { Luzon } \\
\text { Endemic }\end{array}$ \\
\hline \multirow[t]{2}{*}{ Picidae } & Dendrocopos & maculatus & Endemic \\
\hline & Mulleripicus & funebris & Endemic \\
\hline Campephagidae & Coracina & coerulescens & Endemic \\
\hline Irenidae & Irena & cyanogaster & Endemic \\
\hline \multirow[t]{2}{*}{ Pycnonotidae } & Pycnonotus & urostictus & Endemic \\
\hline & Hypsipetes & philippinus & Endemic \\
\hline Dicruridae & Dicrurus & balicassius & Endemic \\
\hline Paridae & Parus & elegans & Endemic \\
\hline Rhabdornithidae & Rhabdornis & mysticalis & Endemic \\
\hline Timaliidae & Stachyris & nigrocapitata & Endemic \\
\hline \multirow[t]{4}{*}{ Sylviidae } & Phylloscopus & olivaceus & Endemic \\
\hline & Phylloscopus & cebuensis & Endemic \\
\hline & Orthotomus & castaneiceps & Endemic \\
\hline & Orthotomus & derbianus & Endemic \\
\hline Muscicapidae & Cyornis & herioti & $\begin{array}{l}\text { Endemic } \\
\text { (Luzon) }\end{array}$ \\
\hline Rhipuduridae & Rhipidura & cyaniceps & Endemic \\
\hline Pachycephalidae & Pachycephala & philippinensis & Endemic \\
\hline Sturnidae & Sarcops & calvus & Endemic \\
\hline \multirow[t]{2}{*}{ Nectariniidae } & Aethopyga & shelleyi & Endemic \\
\hline & Aethopyga & fragrans & Endemic \\
\hline \multirow[t]{6}{*}{ Dicacidae } & Dicaeum & hypoleuсит & Endemic \\
\hline & Dicaeum & pygmaeum & Endemic \\
\hline & Dicaeum & bicolor & Endemic \\
\hline & Dicaeum & trigonostigma & Endemic \\
\hline & Dicaeum & australe & Endemic \\
\hline & Dicaeum & aeruginosum & Endemic \\
\hline \multirow[t]{2}{*}{ Zosteropidae } & Zosterops & nigrorum & Endemic \\
\hline & Zosterops & meyeni & Endemic \\
\hline
\end{tabular}


Table S2. MakiBIS listing of endemic flora in Mt Makiling, Psittacidae Philippines

\begin{tabular}{|c|c|c|c|}
\hline Phylum, Family & Scientific name & & Remarks \\
\hline \multicolumn{4}{|l|}{ Mammals } \\
\hline \multirow[t]{2}{*}{ Pteropodidae } & Haplonycteris & fisheri & Endemic \\
\hline & Ptenochirus & jagorii & Endemic \\
\hline \multirow[t]{3}{*}{ Hipposideridae } & Hipposideros & obscurus & Endemic \\
\hline & Rhinolopus & subrufus & Endemic \\
\hline & Rhinolopus & Virgo & Endemic \\
\hline Vespertilionidae & Myotis & rufopictus & Endemic \\
\hline Crocidurinae & Crocidura & grayi & Endemic \\
\hline \multirow[t]{3}{*}{ Muridae } & Rattus & everetti & Endemic \\
\hline & Chrotomys & mindorensis & Endemic \\
\hline & Phloeomys & cumingi & Endemic \\
\hline Suidae & Sus & philippensis & Endemic \\
\hline Cervidae & Cervus & marianus & Endemic \\
\hline
\end{tabular}

Fishes

Terapontidae Leiopotherapon plumbeus Endemic

$\begin{array}{llll}\text { Amphibians } & & & \\ \text { Ranidae } & \text { Rana } & \text { everetti } & \text { Endemic } \\ & \text { Rana } & \text { magna } & \text { Endemic } \\ & \text { Rana } & \text { woodworthi } & \text { Endemic } \\ \text { Rhacophoridae } & \text { Platymantis } & \text { dorsalis } & \text { Endemic } \\ & \text { Platymantis } & \text { corrugatus } & \text { Endemic } \\ & \text { Platymantis } & \text { guentheri } & \text { Endemic } \\ & \text { Philautus } & \text { surdus } & \text { Endemic }\end{array}$

\section{Reptiles}

Gekkonidae

Scincidae

\begin{tabular}{|c|c|c|c|}
\hline & & \multirow{2}{*}{$\begin{array}{l}\text { decipiens } \\
\text { steerei }\end{array}$} & \\
\hline & & & Endemic \\
\hline & & coxi & Endemic \\
\hline & Otosaurus & cumingi & Endemic \\
\hline Agamidae & Gonocephalus & semperi & Endemic \\
\hline Colubridae & Oligodon & modesdum & Endemic \\
\hline \multirow[t]{3}{*}{ Elapidae } & Cyclocorus & lineatus & Endemic \\
\hline & Naja & philippensis & Endemic \\
\hline & Calliophis & calligaster & Endemic \\
\hline Viperidae & Trimeresurus & flavomaculatus & Endemic \\
\hline \multicolumn{4}{|l|}{ Birds } \\
\hline Accipitridae & Spilornis & holosphilus & Endemic \\
\hline Falconidae & Microheirax & erythrogenys & Endemic \\
\hline \multirow[t]{6}{*}{ Turnicidae } & Turnix & ocellata & $\begin{array}{l}\text { Endemic } \\
\text { (Luzon) }\end{array}$ \\
\hline & Macropygia & tenuirostris & Endemic \\
\hline & Gallicolumba & luzonica & $\begin{array}{l}\text { Endemic } \\
\text { (Luzon) }\end{array}$ \\
\hline & Phapitreron & leucotis & Endemic \\
\hline & Phapitreron & amethystinus & Endemic \\
\hline & Ptilinopus & occipitalis & Endemic \\
\hline
\end{tabular}

$\begin{array}{lll}\text { Bolbopsittacus } & \text { lunulatus } & \text { Endemic } \\ \text { Loriculus } & \text { philippensis } & \text { Endemic } \\ \text { Cacomantis } & \text { sepulcralis } & \text { Endemic } \\ \text { Centropus } & \text { viridis } & \text { Endemic } \\ \text { Centropus } & \text { unifurus } & \text { Endemic } \\ & & \text { (Luzon) } \\ \text { Phaenicophaeus } & \text { cumingi } & \text { Endemic } \\ & & \text { (Luzon) } \\ \text { Phaenicophaeus } & \text { superciolosus } & \text { Endemic } \\ \text { Otus } & \text { megalotis } & \text { Endemic } \\ \text { Ninox } & \text { philippensis } & \text { Endemic } \\ \text { Batrachostomus } & \text { septimus } & \text { Endemic } \\ \text { Collocalia } & \text { troglodytes } & \text { Endemic } \\ \text { Collocalia } & \text { mearnsi } & \text { Endemic } \\ \text { Harpactes } & \text { ardens } & \text { Endemic } \\ \text { Actenoides } & \text { lindsayi } & \text { Endemic } \\ \text { Penelopides } & \text { manillae } & \text { Luzon } \\ & & \text { Endemic } \\ \text { Dendrocopos } & \text { maculatus } & \text { Endemic } \\ \text { Mulleripicus } & \text { funebris } & \text { Endemic } \\ \text { Coracina } & \text { coerulescens } & \text { Endemic } \\ \text { Irena } & \text { cyanogaster } & \text { Endemic } \\ \text { Pycnonotus } & \text { urostictus } & \text { Endemic } \\ \text { Hypsipetes } & \text { philippinus } & \text { Endemic } \\ \text { Dicrurus } & \text { balicassius } & \text { Endemic } \\ \text { Parus } & \text { elegans } & \text { Endemic } \\ \text { Rhabdornis } & \text { mysticalis } & \text { Endemic } \\ \text { Stachyris } & \text { nigrocapitata } & \text { Endemic } \\ \text { Phylloscopus } & \text { olivaceus } & \text { Endemic } \\ \text { Phylloscopus } & \text { cebuensis } & \text { Endemic } \\ \text { Orthotomus } & \text { castaneiceps } & \text { Endemic } \\ \text { Orthotomus } & \text { derbianus } & \text { Endemic } \\ \text { Cyornis } & \text { herioti } & \text { Endemic } \\ & & \text { (Luzon) } \\ \text { Rhipidura } & \text { cyaniceps } & \text { Endemic } \\ \text { Pachycephala } & \text { philippinensis } & \text { Endemic } \\ \text { Sarcops } & \text { calvus } & \text { Endemic } \\ \text { Aethopyga } & \text { shelleyi } & \text { Endemic } \\ \text { Aethopyga } & \text { fragrans } & \text { Endemic } \\ \text { Dicaeum } & \text { hypoleucum } & \text { Endemic } \\ \text { Dicaeum } & \text { pygmaeum } & \text { Endemic } \\ \text { Dicaeum } & \text { bicolor } & \text { Endemic } \\ \text { tricaeumostigma } & \text { Endemic } \\ \text { Eosterops } & \text { australe } & \text { Endemic } \\ \text { nigrorum } & \text { meyeni } & \text { Endemic } \\ \text { Endemic } \\ \text { Dicamic }\end{array}$

